\section{Nest plant selection of the Andaman Crake Rallina canningi, Andaman Islands, India}

\author{
N. Ezhilarasi ${ }^{1}$ \& L. Vijayan ${ }^{2}$ \\ 1,2 Salim Ali Center for Ornithology and Natural History, \\ Coimbatore, Tamil Nadu 641108, India \\ Email: 1ezhilcbe@gmail.com, ${ }^{2}$ vijayanlalitha@gmail.com
}

The Andaman Crake Rallina canningi, is a rare and endemic bird to the Andaman Islands (Collar et al. 1994; Stattersfield et al. 1998; Vijayan et al. 2000, 2005). This bird retained under the category of Near Threatened (BirdLife International 2008), inhabits marshland inside the forests (Taylor \& Perlo 1998). There is paucity of information on the breeding biology of the Andaman Crake (Ali \& Ripley 1969; Taylor \& Van Perlo 1998; BirdLife International 2001) except for the records of nests, eggs (Baker 1934) and casual observations (BirdLife International 2001). Hence, a study was conducted on the breeding biology of the Andaman Crake.

Study Area: Andaman and Nicobar Islands form a major group of oceanic islands in the Bay of Bengal, India, located between $6^{\circ} 5^{\prime}-14^{\circ} 45^{\prime} \mathrm{N}$ \& $92^{\circ}-94^{\circ} \mathrm{E}$. Andaman Islands comprise north, middle, south and little Andaman (Das 1999; Das \& Palden 2001).

Our intensive study was at Pathilevel in North Andaman, where the main forest type is moist deciduous with irregular top storey of predominantly deciduous trees which grow to $40 \mathrm{~m}$ or more harbouring woody climbers. The second storey consists of numerous species with shrubby evergreen undergrowth of Licuala peltata, where the major tree species were Pterocarpus dalbergioides, Terminalia bialata, Bombax insigne and Tetrameles nudiflora.

Date of publication (online): 26 October 2010

Date of publication (print): 26 October 2010

ISSN 0974-7907 (online) | 0974-7893 (print)

Editor: K.R. Sasidharan

Manuscript details:

Ms \# 02467

Received 24 May 2010

Final revised received 17 July 2010

Finally accepted 10 September 2010

Citation: Ezhilarasi, N. \& L. Vijayan (2010). Nest plant selection of the Andaman Crake Rallina canningi, Andaman Islands, India. Journal of Threatened Taxa 2(11): 1301-1302.

Copyright: () N. Ezhilarasi \& L. Vijayan 2010. Creative Commons Attribution 3.0 Unported License. JoTT allows unrestricted use of this article in any medium for non-profit purposes, reproduction and distribution by providing adequate credit to the authors and the source of publication.

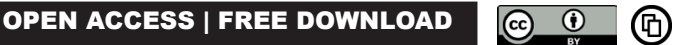

Methods: Nests were located and studied following Martin \& Geupel (1993) and Martin et al. (1997) during May-October 20052006. Ivlev Index of selectivity (1961) - $E=U-A / U+A$, where $U$ is percent utilization of species and A percent availability of the same species was used. Selectivity levels range from -1 to +1 , where $(-)$ indicates avoidance while $(+)$ indicates preference. Mann-Whitney U test (Zar 1999) was used to compare nest- plant character with non-nesting plant.

Results and Discussion: Table1 presents the details of 155 nests on 151 plants belonging to 21 species and 12 families. All nests except three were found on the live plants (two on dead Terminalia catappa (Combretaceae) and one on dead Bouea oppositifolia (Anacardiaceae). Four species, Terminalia nudiflora (Thipok), Pterocarpus dalbergioides (Padauk), Terminalia bialata (White chugulam) and Pterygota alata (Lakko) accounted to $72.12 \%$ while 17 other species together contributed $27.81 \%$ of nest trees.

The preference test showed that Andaman Crake had a higher choice for five species, i.e. Tetrameles nudiflora $(E=0.84)$, Pterocarpus dalbergioides $(E=0.63)$, Terminalia bialata $(E=0.53)$ Pterygota alata $(E=0.83)$ and Celtis timorensis (Thejpathi) $(E=0.68)$, while they avoided 13 species, i.e. Spondias pinnata, Terminalia manii, Endospermum diadenum, Bombax insigne, Pongamia pinnata, Syzygium samarangense, Dillenia indica, Parishia insigni, Pterospermum acerifolium, Bouea oppositifolia, Lannea coromandelica, Miliusa tectona and Celtis timorensis.

The nesting sites of the Andaman Crake were closer to the water source, placed mostly at the bottom of huge trees. Nest plant variables were compared with nonnesting plants and significant differences were recorded in $\mathrm{GBH}$ of the nesting tree. The $\mathrm{GBH}$ of the nesting tree was greater than non-nesting tree $(U=171.5, p<0.05)$ and number of buttresses were comparatively more in nesting tree than non-nesting tree $(\mathrm{U}=12, \mathrm{p}<0.05)$.

Of the 21 species of trees observed, Tetrameles nudiflora and Pterocarpus dalbergioides with bigger and more buttresses and architectural suitability were the most preferred nesting trees as observed by Das (2008).

\section{REFERENCES}

Ali, S. \& S.D. Ripley (1969). Handbook of The Birds of India and Pakistan - Vol II. Oxford University Press, New Delhi, $733 \mathrm{pp}$.

Ali, S. \& S.D. Ripley (1987). A Compact Handbook of The Birds of India and Pakistan. Oxford University Press. New Delhi. Andaman \& Nicobar Islands, GOI-UNDP-GEF Project on Management of Coral Reefs of Andaman \& Nicobar Islands.

Baker, E.C.G. (1934). The Identification of The Birds of The 
Table 1. Nest plant species utilized by the Andaman Crake

\begin{tabular}{|c|c|c|c|c|}
\hline Tree Name & Family & $\begin{array}{l}\text { No. of plants } \\
\text { with nest }\end{array}$ & $\%$ of use & $E$ \\
\hline Spondias pinnata & Anacardiaceae & 1 & 0.66 & -0.27 \\
\hline Terminalia manii & Combretaceae & 2 & 1.32 & -0.47 \\
\hline Endospermum diatenum & Euphorbiaceae & 1 & 0.66 & -0.91 \\
\hline Bombax insigne & Bombacaceae & 7 & 4.64 & -0.35 \\
\hline Pongamia pinnata & Fabaceae & 2 & 1.32 & -0.41 \\
\hline Syzygium samarangense & Myrtaceae & 1 & 0.66 & -0.76 \\
\hline Dillenia indica & Dilleniaceae & 2 & 1.32 & -0.90 \\
\hline Pterygota alata & Sterculiaceae & 18 & 11.92 & 0.86 \\
\hline Parishia insigni & Anacardiaceae & 1 & 0.66 & -0.82 \\
\hline Pterospermum acerifolium & Sterculiaceae & 1 & 0.66 & -0.66 \\
\hline Bouea oppositifolia & Anacardiaceae & 2 & 1.32 & -0.84 \\
\hline Lannea coromandelica & Anacardiaceae & 1 & 0.66 & -0.80 \\
\hline Pterocarpus dalbergioides & Fabaceae & 34 & 22.52 & 0.63 \\
\hline Ficus arnottiana & Moraceae & 1 & 0.66 & 0.18 \\
\hline Miliusa tectona & Annonaceae & 3 & 1.99 & -0.12 \\
\hline Celtis timorensis & \multirow{2}{*}{$\begin{array}{l}\text { Ulmaceae } \\
\text { Tetramelaceae }\end{array}$} & 9 & 5.96 & 0.68 \\
\hline Tetrameles nudiflora & & 37 & 24.50 & 0.84 \\
\hline Terminalia bialata & Combretaceae & 20 & 13.25 & 0.53 \\
\hline Diospyros crumenata & Ebenaceae & 1 & 0.66 & -0.16 \\
\hline Terminalia catappa & Combretaceae & 5 & 3.31 & 0.41 \\
\hline Canarium euphyllum & Burseraceae & 2 & 1.32 & 0.32 \\
\hline
\end{tabular}

Indian Empire - Vol II. Taylor and Francis, London.

BirdLife International (2001). Threatened Birds of Asia. The Bird Life International. Red Data Book, Cambridge, UK. Part A: 2458-2460.

BirdLife International (2008). BirdLife checklist of the birds of the world, with conservation status and taxonomic sources. Version/downloaded from http:// www. Birdlife.org \datazone/ species/downloads/birdlife-checklist-version-1 xip (xls zipped $1 \mathrm{MB})$

Collar, N.J., M.J. Crosby \& A.J. Stattersfield (1994). Birds to Watch 2: The World List of Threatened Birds. International Council for Bird Preservation, BirdLife International, Cambridge, UK, 407pp.

Das, A.K.S. (2008). Bird community structure along the altitudinal gradient in Silent Valley National Park, Western Ghats, India. PhD Thesis. Bharathiar University, Coimbatore.

Das, I. \& J. Palden (2001). Biodiversity and biogeography of the herpetofauna of southern Asia, pp.1-38. In: Bambaradeniya (ed.). An Overview of The Threatened Herpetofauna of South Asia. IUCN Sri Lanka and Asia Regional Biodiversity Programme, Colombo.

Das, I. (1999). A noteworthy collection of mammals from Mount Hariet, Andaman Islands, India. Journal of South Asian Natural History 4(2):181-185.

Ivlev, V.S. (1961). Experimental Ecology of the Feeding of Fishes. Yale University Press, New Haven, USA, 302pp.

Martin, T.E. \& G.R. Geupel (1993). Nest-monitoring plots: Methods for locating nests and monitoring success. Journal of Field Ornithology 64(4):507-519.

Martin, T.E., C. Paine, C.J. Conway, W.M. Hochachka, P. Allen \& Jenkins (1997). Bird Field Protocol. Biological Resource Division, Montana, Cooperative Wildlife Research Unit,
Missoula.Montana, 64pp.

Stattersfield, A.J., M.J. Crosby, A.J. Long \& D.C. Wege (1998). Endemic Bird Areas of The World: Priorities for Biodiversity Conservation. Birdlife Conservation Series No. 7. Birdlife International, UK, 84pp.

Taylor, B. \& B.V. Perlo (1998). Rails. A guide to the Rails, Crakes, Gallinules and Coots of the World. Pica Press, Sussex, 600pp.

Vijayan L., R. Sankaran, K. Sivakumar \& V. Murugan (2000). A study on the Ecology, status and conservation perspectives of certain rare endemic avifauna of the Andaman and Nicobar Islands. Final Report, SACON, 184pp.

Vijayan, L., S.N. Prasad, M.A.R. Mamannan \& P. Kaushik (2005). Avifaunal diversity of the Andaman Islands and their conservation. Final Report, SACON, 84pp.

Zar, J.H. (1999). Biostatistical Analysis - 4th Edition. PrenticeHall, New Jersey, 454pp. 